\title{
ARTIKELEN
}

\section{Theoretische vernieuwing in de criminologie}

\author{
René van Swaaningen \& Marc Schuilenburg
}

'Er is niets nieuws onder de zon.

Wanneer men van iets zegt: "kijk, iets nieuws",

Dan is het altijd iets dat er sinds langvervlogen tijden is geweest.'

Prediker 1:10

\section{Inleiding}

Wanneer een sociale wetenschapper zegt iets nieuws te hebben ontdekt, dan is de reactie vrijwel altijd: 'Wat is daar dan precies zo nieuw aan? Had die en die toen en toen niet al ongeveer hetzelfde gezegd?' Meestal zijn dergelijke tegenwerpingen ook wel juist: echte ontdekkingen worden eerder in de natuurwetenschappen dan in de sociale wetenschappen gedaan. Maar het is ook een gemeenplaats waar we niet zoveel verder mee komen; een gemeenplaats die, zoals blijkt uit het aan het Bijbelboek Prediker ontleende motto bij deze inleiding, al dateert uit oudtestamentische tijden.

Toen de culturele criminologie eind jaren 1990 opkwam, werd ook direct gezegd dat er niets nieuws onder de zon was; dat we vrijwel al deze inzichten al kenden uit het symbolisch interactionisme en de kritisch-criminologische recepties van subculturele theorieën en stadsetnografieën. In de inleiding tot het eerste nummer van dit tijdschrift hebben wij deze kritiek niet willen pareren. In plaats daarvan stelden we dat de meeste theoretische draden die nu samenkomen in de culturele criminologie inderdaad al decennia geleden zijn gesponnen en dat het hoog tijd is dat die waardevolle perspectieven worden vertaald naar een nieuwe tijd. Begin deze eeuw vroeg een nieuwe generatie kwalitatief geschoolde sociale wetenschappers die inmiddels in de criminologie werkzaam was aandacht voor de grote vragen van deze tijd: migratie, mondialisering, beeldcultuur, terrorisme, consumentisme, onveiligheidsgevoelens, radicalisering - en nog veel meer (Schuilenburg et al., 2011: 6).

Dat leek ons eens te meer noodzakelijk, omdat we de Nederlandse criminologie in de jaren 1980 hadden zien verschralen tot een toegepaste beleidsdiscipline, waarin nog maar nauwelijks theoretische vernieuwing plaatsvond en waarbij aan de grote vragen uit de sociale wetenschappen vrijwel geen aandacht werd besteed (Engbersen, 2008). In een recente bijdrage aan een overzichtswerk over de culturele criminologie hebben wij laten zien dat dat momenteel echt anders ligt. Zo wordt in veel recente studies uit de Nederlandstalige criminologie de link met de genoemde grote hedendaagse vragen uit de sociale wetenschappen wel degelijk gelegd. In die zin heeft de culturele criminologie het criminologische landschap in 
intellectuele zin verrijkt en is er wetenschappelijke vooruitgang geboekt (Schuilenburg, Staring \& Van Swaaningen, 2017).

Onze bespreking van Cyrille Fijnauts ideeëngeschiedenis Criminologie en strafrechtsbedeling beginnen wij met een fundamentele vraag over theoretische vernieuwing in de criminologie: 'Het blijft een prikkelende vraag of er in de sociale wetenschappen ook theoretische en methodische vooruitgang wordt geboekt. Leidt de uitbreiding van criminologische kennis bijvoorbeeld tot een beter begrip van wat een crimineel beweegt of hoe criminaliteit het beste kan worden aangepakt? Kunnen we de inzichten van de negentiende-eeuwse Italiaanse School van Lombroso en Ferri over de biopsychologische determinanten van criminelen inmiddels in de prullenbak gooien en dienen wij in plaats daarvan de longitudinale studies van hedendaagse ontwikkelings- en levensloopcriminologen voor waar aan te nemen? En, wanneer het antwoord op deze vraag bevestigend zou zijn, hoe voltrekt het epistemologische proces van waarheidsvinding zich dan; als een gematigde, geleidelijke vooruitgang, als een opeenvolging van verschillende paradigma's of eerder op dialectische wijze?' (Schuilenburg \& Van Swaaningen, 2014: 157) Dit citaat roept de vraag op welke parameters voor theoretische vernieuwing wij zelf hanteren.

\section{Wat is theorie en wat is vernieuwing?}

Het voert te ver om hier diep in te gaan op de vraag wat in de sociale wetenschappen onder een theorie wordt verstaan, maar iets van een definitie willen wij in dit themanummer over theoretische vernieuwing wel geven. Elders hebben wij hier namelijk wel al uitgebreid bij stilgestaan. In een boek over kwalitatieve onderzoeksmethoden in de criminologie hebben Richard Staring en René van Swaaningen (2016) de 'heilige drie-eenheid' onderzoeksvraag-methode-theorie besproken, alsmede de verschillende functies van theorie in inductief en deductief onderzoek. Een theorie wordt hier gedefinieerd als 'een systematische en consistente redenering die volgt uit een generalisering en abstrahering van onderzoeksgegevens, die een mogelijke verklaring aandraagt en die in zo veel mogelijk toetsbare termen is gevat' (2016: 38).

De wetenschapsfilosoof Thomas Kuhn heeft een aantal criteria ontwikkeld, waaraan de kracht van een theorie kan worden afgemeten. Volgens Kuhn (1979: 182) is een goede theorie niet alleen nauwkeurig en consistent, maar heeft zij ook een reikwijdte die verder gaat dan het waargenomen fenomeen op zich, is zij eenvoudig geformuleerd en is zij vruchtbaar voor de analyse van nieuwe onderzoeksvondsten en -velden. In dit verband is het van belang vast te stellen dat aan de ontwikkeling van een theorie in de strikte zin van het woord een conceptualisering voorafgaat via wat Anthony Giddens 'sensitising devices' (1984: 326) heeft genoemd. Dergelijke 'sensitiverende' concepten maken een onderzoeker als het ware ontvankelijk voor fenomenen die hem eerder ontgingen. Op basis daarvan wordt een 'sensitising theory' ontwikkeld, die kan helpen bij de interpretatie van de onderzoeksbevindingen. Een theorie vormt dus een coherent geheel, terwijl 
een concept een veel opener begrip is, dat pas inhoud krijgt in de specifieke invulling ervan.

Een bekend voorbeeld van een dergelijk sensitiverend concept is het begrip 'discipline' in het werk van de Franse filosoof Michel Foucault, dat verwijst naar de manier waarop lichamen tot productieve en efficiënte individuen worden gemaakt in scholen, kazernes en gevangenissen. Dit gebeurt via methoden als roosters, examens en oefeningen. Foucault laat hierbij zien dat het steeds de vraag is hoe disciplinering in verschillende situaties wordt gerealiseerd en daarmee ook steeds een andere vorm en inhoud krijgt. Het concept 'discipline' staat niet op zichzelf, maar maakt onderdeel uit van een bredere machtstheorie. Een uitgangspunt daarvan is dat 'macht' niet moet worden begrepen in negatieve termen, maar als een productieve kracht. Dit impliceert een nieuwe manier van kijken naar een op zich bekend fenomeen.

Bij de vraag naar wat een theorie wetenschappelijk maakt, kijken we vooral naar zaken als de empirische houdbaarheid en methodologische kwaliteit van de dataverzameling waarop de theorie is gebaseerd. Zeker in een tijd waarin 'nepnieuws' en 'alternatieve feiten' het publieke debat beheersen, is dat inderdaad één van de belangrijkste functies van de wetenschap. Maar dat zegt op zichzelf nog niets over de noodzaak tot theoretische ontwikkeling. Wanneer wij die verwaarlozen, verliezen onze theorieën aan analytische scherpte en verklaringskracht. Om tot wetenschappelijke vooruitgang te kunnen komen, zijn volgens Robert Merton (1942) de zogenoemde CUDOS-criteria van belang.

Omdat wetenschappelijke kennis volgens Merton altijd een product is van gezamenlijke inspanningen, dient zij ten eerste openbaar te zijn en dient zij te worden beschouwd als collectief eigendom (Communalism). Ten tweede kenmerkt de beoordeling van het werk als zodanig, dus zonder aanziens des persoons of denkrichting, de juiste wetenschappelijke houding (Universalism). Ten derde horen eigenbelang of groepsbelang geen rol te spelen in de wetenschap (Disinterestedness). In het licht van de huidige discussie over valorisatie van onderzoek is dit een wetenschappelijke eis om nog eens tot ons door te laten dringen. En ten slotte noemt Merton de functie van wetenschap als georganiseerde scepsis (Organized Skepticism): zowel de onderzoeksresultaten als de methodologische verantwoording ervan moeten worden voorgelegd aan collega-wetenschappers, zodat ze kritisch tegen het licht kunnen worden gehouden, het duidelijk is hoe de uitkomsten verkregen zijn en er open discussies kunnen worden gevoerd. Mertons idee van georganiseerde scepsis is vooral van belang om datgene wat in een bepaalde tijd als 'de waarheid' wordt beschouwd kritisch tegen het licht te houden. Daarom is een sceptische houding van groot belang voor theoretische vernieuwing.

Over het antwoord op de vraag wat in de wetenschap onder vernieuwing moet worden verstaan, zijn de meningen verdeeld. De wetenschapsfilosoof Karl Popper (1935) meende dat theoretische vernieuwing plaatsvindt, omdat er naar een mogelijke verklaring voor wetenschappelijke problemen of kennistekorten wordt gezocht, waarvoor een theorie een voorlopige oplossing biedt, tot het moment dat zij door nieuwe onderzoeksgegevens wordt gefalsificeerd, waarna het hele proces van theorievorming zich weer herhaalt en wij steeds dichter bij 'de waarheid' komen. Als we het hier zouden hebben over de natuurwetenschappen, waarin bij 
theoretische vernieuwing het accent veel meer ligt op nieuwe ontdekkingen, kunnen wij ons hier best aardig in vinden, maar wij vragen ons af in hoeverre deze positivistische, of beter gezegd, kritisch-rationalistische manier van denken wel toepasbaar is op de sociale wetenschappen.

Desondanks is Popper van grote invloed geweest op het denken over theoretische vernieuwing in de sociale wetenschappen. Maar: wij zijn geen 'popperianen'. Het gaat bij sociaalwetenschappelijke theorieën volgens ons veel meer om het zoeken naar adequate manieren om (nieuwe) sociale fenomenen eerst te begrijpen (verstehen) en daarna om op basis van onderzoek tot plausibele verklaringen te komen. Aan waarheidsvinding komen we in de sociale wetenschappen nauwelijks toe, omdat sociale fenomenen zelden als 'waar' of 'niet waar' kunnen worden getypeerd; enerzijds omdat onze 'feiten' zelden hard genoeg zijn en anderzijds omdat wij zelf deelnemer zijn aan het veld dat wij onderzoeken en het daardoor nauwelijks 'objectief' kunnen waarnemen. De etymologie van het woord 'feit' maakt dat trouwens ook al duidelijk. Het Latijnse woord factum, waarvan het is afgeleid komt van het werkwoord facere, dat 'maken' betekent. Als we spreken over een 'feit' in ontologische zin, als iets wat werkelijk 'is', dan moeten we ons dus realiseren dat het werkelijke altijd door onszelf is geconstrueerd.

Als criminologen voelen we ons daarom meer thuis bij Thomas Kuhns idee van 'wetenschappelijke revoluties', waarin Poppers idee van een in harmonie werkende wetenschappelijke gemeenschap die gezamenlijk dichter bij de waarheid wil komen wordt verworpen en waarin wetenschappelijke ontwikkeling wordt voorgesteld als een schoksgewijs verlopend sociaal proces, waarbij een bepaald idee vrij plotseling in bredere kring aan aanhang wint en daardoor tot een wetenschappelijke omslag leidt, terwijl een vergelijkbaar idee een paar decennia eerder misschien nog onopgemerkt bleef en tot geen enkele verandering van de dominante wetenschappelijke inzichten leidde. Anders dan Popper ziet Kuhn (1972) wetenschappelijke vernieuwing primair als een exponent van een verandering van het dominante paradigma of, zoals Kuhn het zelf noemt, van een verandering van wereldbeschouwing. Hij onderscheidt hierbij drie fasen in een wetenschappelijke ontwikkeling: de pre-paradigmatische fase, de normale en de revolutionaire fase. Waar Kuhn het heeft over paradigmawisselingen in de wetenschap, gebruikt Michel Foucault (1966), in zijn boek De woorden en de dingen, het begrip epistèmè (en later een discours, ofwel een vertoog) in de menswetenschappen. Een epistèmè is in Foucaults optiek een 'archeologische' grondstructuur die samenhang verleent aan het weten in een bepaalde periode. Dat weten omvat alle uitingen die door mensen als 'waar' worden ervaren. De wetenschap is hiervan een voorbeeld, maar niet het enige voorbeeld. Het gaat namelijk om alle uitspraken, of ze nu worden gedaan op de opiniepagina van de krant, in de politieke arena of in de wetenschap. Foucault maakt hierbij een onderscheid tussen drie historische perioden die elk worden gekenmerkt door een eigen logica en kenstructuur: de Renaissance, de klassieke periode en de moderniteit. Daarbij maakt hij duidelijk dat kennis zich ontwikkelt in nauwe samenhang met veranderende machtsverhoudingen: uitgedrukt in zijn bekende savoir-pouvoir-beginsel (1976). Alleen kennis die binnen het heersende vertoog (discours) past, wordt wetenschappelijk genoemd. Een voorbeeld hiervan is de erfelijkheidstheorie van Gregor Mendel, die halverwege de 
negentiende eeuw wel degelijk 'de waarheid' bleek te bevatten over de manier waarop de overerving van erfelijke eigenschappen verloopt, maar die toch volledig werd genegeerd in de biologie van zijn tijd. Eerst moest een ander vertoog of discursief regime ontstaan, voordat de wetten van Mendel voor 'waar' konden worden aangenomen.

\section{Wetenschappelijke vernieuwing in de criminologie}

Laat ons nu onze blik op de criminologie zelf richten: wat zijn de grote theoretische veranderingen die hebben plaatsgevonden bij de wetenschappelijke bestudering van vraagstukken rond 'misdaad en straf' of, in meer sociologische zin, van deviantie en sociale controle? Wij beschouwen de ontwikkeling van de criminologie hier in de context van (1) historische en culturele ontwikkelingen, (2) politiekeconomische ontwikkelingen, (3) ontwikkelingen in andere wetenschapsgebieden en (4) al dan niet dialectische reacties op of specificeringen van andere theoretische perspectieven binnen het eigen wetenschapsgebied. Dit onderscheid is vooral van analytische aard. In werkelijkheid lopen deze vier factoren dwars door elkaar.

In een themanummer over theoretische vernieuwing in het Tijdschrift voor Criminologie uit 2007 is vooral een wetenschapsinterne blik op ontwikkelingen binnen ons vakgebied geboden. Volgens popperiaanse traditie schetsen Edward Kleemans, Frank Weerman en Els Enhus (2007) hierin de routes naar theoretische vernieuwing als (1) een zoektocht naar een alomvattende theorie, (2) het signaleren van kennisproblemen, (3) het agenderen van vergelijkbare vragen uit andere wetenschapsgebieden en (4) de wisselwerking tussen theorie en empirie binnen de criminologie zelf. Herijking van bestaande criminologische theorieën, toepassing van concepten en denkwijzen uit de gedragsecologie, theoretische vernieuwing die voortvloeit uit nieuwe onderzoeksbevindingen en theoretische integratie spelen hierbij een centrale rol. Een eerder nummer van hetzelfde tijdschrift over theoretische integratie had een vergelijkbare insteek (De Haan, 1998). In de inleiding tot een themanummer over kwalitatief onderzoek in de criminologie werd gesteld dat hierdoor belangrijke wetenschappelijke vernieuwing kan worden geboekt, omdat in kwalitatief onderzoek andere vragen worden gesteld en andere fenomenen en processen worden belicht dan in mainstream onderzoeksdesigns (Kleemans et al., 2008: 325).

Hiermee raken we aan de wetenschapsexterne factoren die waarschijnlijk een (nog) belangrijker rol spelen bij theoretische vernieuwing. Deze nemen van meet af aan een centrale plaats in in het tijdschrift over theoretische ontwikkelingen bij uitstek: Theoretical Criminology. In het eerste nummer kondigden de redacteuren Piers Beirne en Colin Sumner (1997) aan dat zij alle criminologisch relevante bijdragen uit de sociologie, geschiedwetenschap, culturele antropologie, recht, politicologie, psychologie, rechts- en algemene filosofie, psychiatrie, economie, (sociale) geografie en ontwikkelingsstudies verwelkomen, en dat zij ook nadrukkelijk de link willen leggen tussen wetenschap en sociale en politieke bewegingen zoals de milieubeweging of het feminisme en het conservatisme of het socialisme. Maar 
Beirne en Sumner geven ook aan dat zij met Theoretical Criminology geen vehikel willen zijn om welke politieke stroming dan ook van een wetenschappelijk sausje te voorzien: of het nu gaat om claims van feministen, antiracisten en milieuactivisten of die van overheidsdienaren. Dit laatste punt is eens te meer relevant, omdat de criminologie zich volgens David Garland (2002: 17), anders dan veel andere wetenschapsgebieden, altijd in wisselwerking met externe factoren, zoals met name telkens veranderende praktijkbehoeften en politieke prioriteiten, heeft ontwikkeld. Daardoor heeft de criminologie volgens Garland ook een relatief zwakke epistemologische basis.

\section{Theoretische vernieuwing in de begindagen van de criminologie}

In de Gouden Eeuw, na de Reformatie, in de aanloop tot de Verlichting, begon de schilderkunst, zeker in de Nederlanden, sterk van karakter te veranderen. Heiligenbeelden en schilderijen van Bijbelse taferelen maakten plaats voor portretten van de burgerij, landschappen, interieurs, markten en 'huishoudens van Jan Steen'. Kwam dit door een technische vernieuwing in de schilderkunst of door een veranderd inzicht van de schilders? Nee: de Reformatie en de opkomst van de burgerij hadden ervoor gezorgd dat de centrale rol van de kerk als mecenas van de kunsten aan invloed inboette en daarmee kwam er ook ruimte voor andere, meer alledaagse afbeeldingen. Een dergelijke ontwikkeling zien we rond diezelfde tijd ook in de wetenschap. Terwijl Copernicus' ideeën over een wetenschappelijke kosmologie in de zestiende eeuw nog op religieuze gronden werden verworpen, maakte het mythische denken in de zeventiende eeuw met Galilei's bewegingsleer langzaam maar zeker plaats voor een analytisch denken. Dit gegeven was voor Thomas Kuhn het eurekamoment, waardoor hij kwam met zijn idee over wetenschappelijke revoluties.

De geboorte van de criminologie als zelfstandige tak van wetenschap is direct beïnvloed door ontwikkelingen uit andere wetenschapsgebieden. Het idee dat persoonskenmerken een relatie zouden hebben met lichamelijke kenmerken was al bekend vanuit de cranologie en de frenologie, waarin respectievelijk schedel- en hersenstructuren werden bestudeerd, maar de theoretische vernieuwing die in 1876 door Cesare Lombroso met zijn begrip 'atavisme' tot stand werd gebracht, kan niet los worden gezien van de door Charles Darwin in 1859 ontwikkelde evolutietheorie en de toepassing daarvan op de sociale omgeving in het sociaal-darwinisme van Herbert Spencer uit 1864: de delinquente mens was blijven steken in een vroegere fase van de evolutie en het bestaan van een onderklasse was daarmee een onvermijdelijk gevolg van natuurlijke selectie.

Ook de theorie waarmee het meest nadrukkelijk tegen Lombroso's visie werd ingegaan, gaat terug op de biologie en de medische wetenschap. Zo ontwikkelde de arts Alexandre Lacassagne zijn milieutheorie nog geen twee decennia nadat Louis Pasteur rond 1860 de microbe als ziekteverwekker had ontdekt. De voedingsbodem voor criminaliteit lag volgens de Lacassagne in maatschappelijke omstandigheden. Op het eerste criminologische congres in 1885 in Rome gebruikte Lacassagne hiervoor de aan Pasteur ontleende metafoor dat de crimi- 
neel een microbe is die slechts kan gedijen in een daartoe geschikt sociaal milieu (Fijnaut, 2014: 285-288).

Begin twintigste eeuw lieten vooral de moderniseringstheorieën van Émile Durkheim en Max Weber hun sporen na in de criminologie. De ecologische theorie van de Chicago School van Clifford Shaw en Henry McKay en van Robert Park en Ernest Burgess, waarin de ontwikkeling van criminaliteit werd gekoppeld aan de snelle ontwikkeling van de stad en de wisselende oorsprong van haar bewoners, is hiervan een goed voorbeeld. Er zijn ook talrijke actuele vertalingen van de erfenis van de Chicago School. Zo beschreef Robert Putnam (2000) dat het laatmoderne proces van anonimisering van de samenleving tot een afnemend sociaal kapitaal leidt, dat op zijn beurt weer leidt tot een daling van het vertrouwensniveau in de overheid en vervolgens tot minder participatie van burgers. Omgekeerd toont onderzoek van Robert Sampson (2012) aan dat een sterke organisatorische infrastructuur in buurten gepaard gaat met een grotere bereidheid om zich in te zetten voor het collectieve belang: de zogenoemde 'collective efficacy'.

Maar ook politieke ontwikkelingen, beïnvloed door die andere van de drie grote sociologen, Karl Marx, lieten al snel hun sporen achter in de ontwikkeling van de criminologie. De opkomst van het socialisme halverwege de negentiende eeuw, en Friedrich Engels' boek Die Lage der arbeitenden Klasse in England uit 1845 in het bijzonder, vinden in 1905 een vertaling in het werk over criminaliteit en maatschappelijke omstandigheden van Willem Bonger. Veel vormen van criminaliteit vonden volgens Bonger hun oorsprong in de miserabele omstandigheden waaronder de arbeidersklasse moest zien te overleven en klassenjustitie was een reflectie van maatschappelijke ongelijkheid.

Ook de theorie over sociale structuur en anomie van Robert Merton uit 1938, waarin de 'strain to anomie' van de 'have-nots' als de belangrijkste verklaring voor alledaagse criminaliteit wordt gepresenteerd, heeft duidelijke wortels in het marxistische denken. In zijn werk zelf blijft dit wat impliciet, maar in een interview met Francis Cullen en Steven Messner (2007: 25-29) gaat Merton wel uitgebreid in op het feit dat zijn persoonlijke ervaringen met de ongelijke klassenstructuur van de Noord-Amerikaanse samenleving en zijn vroege kennismaking met het werk van Karl Marx aan de basis lagen van zijn theorie. In ditzelfde interview geeft Merton aan dat het gebrek aan inzicht in de krachten die klassenongelijkheid produceren en in stand houden de reden is waarom hij de studies van de Chicago School nooit erg overtuigend heeft gevonden.

In relatie met de tijdsbepaaldheid van de opkomst van bepaalde theorieën is het vermeldenswaard dat Mertons theorie ook was ingegeven door de maatschappelijke gevolgen van de beurskrach van 1929, toen de zogenoemde American Dream een eerste knauw kreeg en mensen zich realiseerden dat hard werken niet altijd leidde tot grotere welvaart. Iets later, in 1940, munt Edwin Sutherland het begrip 'white collar crime' (witteboordencriminaliteit), waarmee hij als eerste het accent verlegt van de criminaliteit van de 'powerless' naar die van de 'powerful'.

Een dergelijke ontwikkeling is ook niet denkbaar zonder dat we kijken naar de maatschappelijke ongelijkheid die in de criminologie tot dan toe vooral is gereproduceerd. Om witteboordencriminaliteit te verklaren was volgens Sutherland theoretische vernieuwing nodig, omdat de gangbare, op persoonlijke of maatschappe- 
lijke tekortkomingen gebaseerde theorieën, analytisch geen houvast boden. Witteboordencriminelen kwamen niets tekort, niet in materiële noch in cognitieve zin; hun delinquentie werd volgens Sutherland vooral veroorzaakt doordat hebzucht door peers als dominante norm wordt gereproduceerd: 'greed is good...' Met deze woorden portretteert regisseur Martin Scorsese in de film The Wolf of Wall Street uit 2013 het exorbitante leven van beurshandelaar Jordan Belfort, die met de verkoop van aandelen rond een miljoen dollar per week weet binnen te halen. In dit verband is het ook interessant om ons de vraag te stellen waarom het socialisme wel zulke duidelijke sporen heeft achtergelaten in de ontwikkeling van de criminologie, maar het eveneens vanuit het marxisme ontstane anarchisme niet of nauwelijks. Onze hypothese is dat het anarchisme te zeer buiten 'de orde van het vertoog' valt, omdat de grondvesten van de criminologie als legitiem vakgebied als zodanig ermee ter discussie worden gesteld. Omdat het idee van een staat die de orde bewaakt zo'n centrale plaats in de criminologie inneemt, wordt het denken dat daar niet van uitgaat niet serieus genomen. Dat is des te opmerkelijker, omdat door anarchisten als Peter Kropotkin of Michail Bakunin fundamenteel is nagedacht over de oorzaken van criminaliteit en zij ook concrete voorstellen hebben gedaan om de strafrechtsbedeling anders in te richten (Schuilenburg \& Van Steden, 2014). Pas veel later, eind jaren 1970, vond met het abolitionisme een anarchistisch perspectief op straffen zijn ingang in de criminologie (Van Swaaningen, 1997: 116-134). In de culturele criminologie is het anarchistische perspectief vooral door Jeff Ferrell (1998) uitgewerkt. Wanneer we kijken naar de huidige populariteit van buurttops, buurtwachten, buurtcoalities, 'buurt bestuurt'-projecten en andere niet-statelijke manieren van criminaliteitsbeheersing, dan zouden we zelfs kunnen spreken van een veiligheidsbeleid dat anarchistische trekken vertoont. ${ }^{1}$

Het is eveneens opmerkelijk dat in de Sovjet-Unie onder Stalin de criminologie als bourgeois verschijnsel werd weggezet, omdat ze criminaliteit ten onrechte zou beschouwen als een gevolg van individuele kenmerken of keuzes, terwijl de werkelijke oorzaak ervan in de uitbuiting van de arbeidersklasse lag. En, omdat die in een socialistische samenleving tot het verleden behoorde, bestond er in de SovjetUnie sowieso geen criminaliteit meer; alleen contrarevolutionaire daden van egoïsten die hun individuele bezit niet wilden delen en van geestelijk gestoorden (Fijnaut, 2014: par. 9.3).

Een andere politiek gestuurde 'vernieuwing' van de criminologie vond plaats in de aanloop tot de nazitijd. Indicatief hiervoor is het feit dat Franz Exners boek Kriminalsoziologie uit 1936 in 1939 plotseling Kriminalbiologie heette; een term die vanaf 1924 stond voor het leggen van relaties tussen criminaliteit en gedegenereerde ('entartete') bevolkingsgroepen als Joden, zigeuners, homoseksuelen, anarchisten of Slavische volkeren, en die in toenemende mate dienstbaar werd gemaakt aan het 'nieuwe strafrecht' van de nazi's (Fijnaut, 2014: par. 9.2).

1 Omdat dergelijke initiatieven echter niet in het leven zijn geroepen om de legitimiteit van de staat ter discussie te stellen en de regie zelfs is overgenomen door de overheid, moeten we deze ontwikkeling misschien eerder zien als een exponent van de neoliberale 'participatiemaatschappij', die de verzorgingsstaat zou moeten vervangen. 
Mede als gevolg van deze morele ontsporing van biologisch geïnspireerde perspectieven in de criminologie werd de biosociale onderzoeksagenda van Wouter Buikhuisen eind jaren 1970 nog neergesabeld als een 'fout' soort onderzoek. Maar wat dertig jaar na de Tweede Wereldoorlog nog niet kon, was in de jaren 1990 alweer heel gewoon geworden. Vanaf dat moment zou de biosociale criminologie, mede als gevolg van belangrijke ontwikkelingen in de neurologie en de ontdekking van het humane genoom, een belangrijke vernieuwingsimpuls blijken (Blokland et al., 2005). Ook deze geschiedenis biedt een mooie illustratie van de relatie tussen de wetenschapsexterne en wetenschapsinterne factoren die een rol spelen bij theoretische vernieuwing en die ertoe hebben geleid dat genen, IQ en etniciteit centrale onderzoeksthema's zijn geworden in de sociale wetenschappen in het algemeen, en in de psychologie en de criminologie in het bijzonder.

\section{Van een criminologie van de 'lawbreaker' naar een criminologie van de 'lawmaker'}

De beladen geschiedenis van een op het individu gerichte etiologische criminologie is tevens de reden waarom de naoorlogse ontwikkeling van de criminologie zo sterk is beïnvloed door sociologische inzichten uit de Verenigde Staten. Vooral de in de jaren 1950 en 1960 opkomende tegencultuur heeft een enorm creatieve periode in de criminologie ingeluid, waarin we diverse radicale veranderingen van het vakgebied hebben meegemaakt. Vanaf, laten we zeggen, 1956, met de introductie van de neutraliseringstheorie van David Matza en Gresham Sykes, gaat het in de criminologie steeds minder over oorzaken van criminaliteit en steeds meer over de sociale reacties op deviantie. Vooral de labellingbenadering leidt tot een belangrijke perspectiefwisseling. In plaats van onderzoek naar deviante gedragingen komt er onderzoek naar degenen die anderen etiketten als 'crimineel' opplakken.

Met de introductie van de labellingbenadering in Nederland, eind jaren 1960, worden ook hier de gangbare definities in de criminologie ter discussie gesteld. De eerste keer dat er in de tot dan toe bijna uitsluitend etiologische Nederlandse criminologie expliciet aandacht aan sociale reacties op criminaliteit werd besteed, was in Ger Kempe's Inleiding tot de criminologie uit 1967. Tien jaar daarna is het beeld totaal veranderd: in 1977 gaat meer dan de helft van de criminologische inleiding Tegen de regels over de wijzen waarop met name door strafrechtelijke instanties op criminaliteit wordt gereageerd (Fiselier et al., 1977). Aan etiologie wordt nog maar nauwelijks aandacht besteed. Het is tevens interessant om te zien dat een 'conservatieve' variant van het sociale reactie-denken, zoals vervat in Travis Hirschi's bindingen-theorie uit 1969, pas midden jaren 1980 in Nederland invloed kreeg, terwijl Hirschi's idee dat de vraag waarom mensen geen criminaliteit plegen een veel interessantere is dan de vraag waarom zij het wel doen, ook tamelijk revolutionair was. De reden hiervoor is waarschijnlijk, wederom, in de tijdgeest gelegen: die was in 1969 nog wars van 'burgerlijke' ideeën over sociale controle en in 1985 omarmde men die des te meer. 
Eind jaren 1960, wanneer maatschappelijke bewegingen als de Black Panthers, de anti-Vietnambeweging en het feminisme een belangrijk stempel op de samenleving beginnen te drukken, barst er in de Noord-Amerikaanse criminologie een debat los tussen symbolisch-interactionisten en structuralisten, dat bekend is geworden als de 'Becker-Gouldner-controverse'. In 1967 stelt Howard Becker, in zijn essay Whose side are we on?, dat de stem van de 'gelabelden' in de criminologie onvoldoende wordt gehoord en dat het idee dat je als criminologisch onderzoeker een neutrale positie kunt innemen een illusie is. Een jaar later antwoordt Alvin Gouldner (1968) dat dit weliswaar een sympathiek, maar ook wel uiterst romantisch idee is dat lang niet ver genoeg gaat, omdat binnen de labellingbenadering structurele machtsrelaties die de mogelijkheid tot stigmatisering bepalen niet ter discussie worden gesteld. In Europa, en dan vooral in Engeland, markeert dit het begin van de kritische criminologie.

De duidelijkste reflectie van de tijdgeest in de kritische criminologie is gelegen in de ontwikkeling van de 'moral panic'-theorie, waarmee een analyse wordt geboden van de wijze waarop zowel gewelddadige als vreedzame uitingen van jongerenprotest door groepen 'mods', rockers en hippies werden opgeblazen tot mythische proporties; als zouden zij het arbeidsethos en de moraal van de samenleving als geheel ondermijnen (Cohen, 1972; Young, 1971). Doordat, naast politie en justitie, de media een belangrijke rol speelden bij het tot stand komen van dergelijke 'moral panics' kwam er begin jaren 1970 ook een heel onderzoeksgebied bij in de criminologie: mediastudies en discours-analyse.

Het idee hierachter is dat maatschappelijke reacties op bepaalde gebeurtenissen sterk worden beïnvloed door kranten, televisie en later door internet en sociale media. Niet alleen bepalen zij (om journalistieke, politieke of commerciële redenen) welke onderwerpen wel en welke niet aan de orde worden gesteld, maar tevens bieden deze media een platform voor zogenoemde morele kruisvaarders (moral entrepreneurs); een term van Howard Becker uit zijn boek Outsiders (1963: $147 \mathrm{ff}$ ), waarmee hij doelt op mensen die problemen op een moraliserende manier willen agenderen en anderen hierbij willen overtuigen van hun gelijk. Deze theorie is nog steeds erg populair om de reacties te onderzoeken op gebeurtenissen of groepen die als een morele bedreiging worden gezien voor de samenleving, zoals moslimjongeren (Bouabid, 2018).

Van alle sociale bewegingen die hun stempel op de ontwikkeling van de kritische criminologie hebben gedrukt (van jeugdculturen tot mijnwerkersvakbonden tot gedetineerdenbewegingen) heeft het feminisme de criminologie misschien nog wel het meest duurzaam beïnvloed. Carol Smarts (1976) boek Women, Crime and Criminology gaf het startschot voor een feministische kritiek op dit vrijwel uitsluitend op mannen gerichte vakgebied en vanuit de vrouwenbeweging is, met wat begon als een strijd tegen seksueel geweld, uiteindelijk een invloedrijke, algemene slachtofferbeweging en een kritische victimologie ontwikkeld. Het is opmerkelijk dat de antiracismebeweging nooit die invloed op de criminologie heeft gehad als de vrouwenbeweging. Waarschijnlijk moeten we concluderen dat 'etnische minderheden' nog minder op het netvlies van de overwegend blanke, mannelijke academici stonden dan vrouwen. 
De kritische criminologie mag in Nederland dan niet die sterke positie hebben gehad die zij in met name Engeland of Argentinië heeft gehad, ook in veel Nederlands criminologisch onderzoek dat tussen 1970 en 1985 is verricht, is een sterk maatschappelijk engagement te bespeuren: de 'autoriteiten' worden met scepsis bekeken en veel wetenschappelijke debatten worden via ideologische lijnen gevoerd (Van Swaaningen, 2014).

René van Swaaningens (1997) boek Critical Criminology is tijdens de volgende epistemologische omwenteling geschreven. De maatschappelijke basis van de kritische criminologie was met het uitdoven van veel sociale bewegingen nagenoeg verdwenen en politiek links had niet langer de wind mee. Naast een analyse van dat proces is dit boek ook een zoektocht naar een nieuwe relevantie voor de kritische criminologie. Hierbij moeten we overigens vaststellen dat de richtingen waarin de auteur de vernieuwing heeft gezocht (de formulering van een links veiligheidsbeleid en de herijking van de rol van de rechtsstaat en mensenrechten in de kritische criminologie) maar ten dele overeenkomen met hoe het in de 21ste eeuw uiteindelijk is gelopen: de kritische criminologie werd langzaam maar zeker een culturele en een mondiale criminologie. Maar daar moest eerst nog een tijdje overheen gaan; een tijd waarin de etiologie, met name op het individuele niveau van de persoon van de dader, weer een centrale rol ging spelen.

\section{Criminologie in neoliberale tijden}

Naast een heropleving van de biocriminologie worden in de jaren 1990 vooral rationele keuzebenaderingen populair. Dat laatste paradigma past goed bij de toen dominant geworden neoliberale tijdgeest, waarin vrijwel alles op grond van micro-economische parameters wordt beoordeeld, alles als een 'keuze' wordt voorgesteld en alles wordt beschouwd als iemands eigen verdienste of eigen schuld. De populariteit van de rationele keuzebenaderingen is vooral gelegen in het feit dat ze zo eenvoudig in beleidstermen zijn te vertalen: zo had je als beleidsmaker eindelijk eens iets aan die criminologie! In analytische zin is het echter nogal een armoedig, plat verhaal.

Op een heel andere manier past de eerder deterministische biocriminologie eveneens bij de neoliberale tijdgeest. Het neoliberalisme impliceert een mensbeeld waarin concurrentie en eigen verantwoordelijkheid de sleuteltermen zijn. Burgers worden aangemoedigd om zichzelf voortdurend te 'verbeteren'. We kunnen hierbij denken aan scholen die toets- en testfabrieken zijn geworden, waarin kinderen continu worden getraind om betere 'testmakers' te worden, waarbij de vraag wat kinderen nu precies zouden moeten leren op de achtergrond raakt. Tegelijk is het neoliberalisme een bestuurspraktijk, waarin een positieve gedragsnorm wordt geformuleerd waaraan burgers moeten voldoen en die tot doel heeft een samenleving sterker en gezonder te maken. Naast de eerdergenoemde ontwikkelingen in met name de neurologie kan de populariteit van biocriminologisch onderzoek naar 'slechte' genen en IQ dan ook worden verklaard vanuit het idee dat een 'gezonde' samenleving leidt tot minder criminaliteit en een hogere productiviteit. 
Ook zien we vanaf deze tijd vooral integratieve theorieën populair worden. Wij wijzen hierbij op Riekent Jongman en Harrie Timmermans integratie van bindingen en spanningsbenaderingen uit 1985; John Braithwaite's theorie over 'reintegrative shaming' uit 1989, waarin vooral elementen uit de labelling- en de bindingenbenadering zijn te herkennen; Charles Tittle's controle-balanstheorie uit 1995, die hier deels een antwoord op is; ${ }^{2}$ Robert Agnews General Strain Theory uit 1992, waarin de negatieve interacties tussen het individu en zijn directe sociale omgeving als de belangrijkste oorzaak van delinquentie worden gezien; en op David Farringtons Integrated Cognitive Antisocial Potential (ICAP)-theorie uit 2003, waarin levensloopcriminologische inzichten worden geplaatst binnen een langetermijnontwikkeling waarin 'strain' (spanning) een centrale rol speelt. Hier is niet zo zeer sprake van een wetenschappelijke revolutie of een paradigmatische omwenteling, maar van een verfijning, specificering en andere toepassing van bestaande criminologische theorieën.

Een andere belangrijke culturele verandering die ook in deze tijd plaatsvond, is wat Hans Boutellier (1993) de 'victimalisering van de moraal' heeft genoemd. Hoewel het toegenomen belang van het slachtoffer in ons denken - en ons beleid - over veiligheid een bijzonder relevante ontwikkeling is, heeft het in Nederland niet tot noemenswaardige theoretische vernieuwing geleid. Waar in België een groep onderzoekers rond Lode Walgrave de, aan het werk van John Braithwaite ontleende, herstelrechtbenadering van een theoretisch criminologisch fundament heeft proberen te voorzien, bleef het herstelrecht in Nederland vooral het domein van juristen - en heeft het ook veel minder voet aan de grond gekregen dan in België. ${ }^{3}$ Nederlandse criminologen hebben veel meer gedaan met Braithwaite's ideeën over toezicht - met name op het terrein van de organisatiecriminaliteit. En anders dan in Engeland, waar vanuit de feministische criminologie is gepoogd een kritische victimologie tot stand te brengen, hebben Nederlandse victimologen eerder een empiristische koers gevaren.

In Nederland is er tussen 1980 en eind jaren 1990 eigenlijk niet zo heel veel gebeurd in de criminologie. Sterker nog: zij was op sterven na dood. De vraag hoe het is gekomen dat zij vanaf het begin van de 21ste eeuw weer zo populair is geworden, wordt vooral gerelateerd aan het feit dat criminaliteit vooral in de laatste jaren van de vorige eeuw als een van de belangrijkste maatschappelijke problemen wordt gezien (Boutellier, 2002). Ook in de media wordt er flink meer over bericht dan daarvoor. Hoewel criminologen populaire (of populistische) ideeën over criminaliteit ook toen vooral zijn blijven relativeren, krijgen zij in de media niet langer het etiket van 'goedpraters' opgeplakt. De criminoloog wordt inmiddels gezien als iemand die bijdraagt aan een effectievere aanpak van de criminaliteit. Daarnaast heeft een aantal parlementaire enquêtes - en dan met name die van de commissie-Van Traa - het imago van het vak ook in positieve zin beïnvloed. Vervolgens komen er ook veel nieuwe banen voor criminologen: de politie

2 In Theoretical Criminology, 1(1), 77-110 is hierover een interessante gedachtewisseling opgenomen tussen Braithwaite en Tittle.

3 In 2016 heeft Jacqueline de Savornin Lohman als 'significant other' in het Tijdschrift over Cultuur \& Criminaliteit 6(3), 91-103 hiervoor een aantal redenen gegeven. 
wil de misdaadanalyse professionaliseren, in veel gemeenten worden afdelingen voor lokaal veiligheidsbeleid opgericht, de forensische accountancy komt op, enzovoort (Van de Bunt \& Van Swaaningen, 2003). Kortom: de wederopleving van de criminologie in Nederland is rond de afgelopen eeuwwisseling vooral te danken aan het beleidsnut dat er aan werd toegekend. Theoretische vernieuwing zou echter nog even op zich laten wachten.

In de 21ste eeuw verbreedt de criminologie zich langzaam maar zeker echter ook weer en vindt zij weer aansluiting met de centrale debatten die dan in andere sociale wetenschappen worden gevoerd. Mondialisering is misschien wel de economische, culturele, ideologische en maatschappelijke mal van het begin van de nieuwe eeuw. Mondialisering nam al een tijdje een centrale plaats in de sociale wetenschappen in, maar in de criminologie is dit thema pas vrij recent ontgonnen. In zijn oratie analyseert René van Swaaningen (2007) de relatie tussen mondialiseringsprocessen en criminologische problemen als de beperkte relevantie van criminologische inzichten buiten de westerse wereld; de opwarming van de aarde en het belang van zowel milieuregels als het erkennen dat er ook andere relevante entiteiten zijn dan mensen; migratie, militarisering van grenscontrole, mensensmokkel en de ontwikkeling van multiculturele megasteden; in het mondialiseringsproces veranderende ideeën over soevereiniteit en mensenrechten; en de implicaties van cyberspace voor de criminologiebeoefening. Met deze 'nieuwe' maatschappelijke en wetenschappelijke vragen dient zich ook een nieuwe epistemologische omwenteling in de criminologie aan; eentje waarin het antropocentrische en het 'koloniale' karakter van het vakgebied ter discussie wordt gesteld en waarin vervolgens een groene, cyber- en een kritisch kosmopolitische criminologie ontstaat.

\section{Bijdragen aan theoretische vernieuwing in dit themanummer}

Op een flink aantal van deze 'nieuwe' vragen gaan de auteurs in dit themanummer nader in. In die zin zijn de meeste bijdragen in dit themanummer te kenschetsen als aanzetten tot theoretische vernieuwing: nieuwe thema's, die andere vragen oproepen en die ook andere verklarende kaders behoeven. Bij dit alles wordt op theoretisch niveau vooral inspiratie geput uit perspectieven waarin de verwevenheid van menselijke en niet-menselijke entiteiten wordt gethematiseerd die nog maar nauwelijks hun weg in de criminologie hebben gevonden. Klassieke tegenstellingen zoals subject-object, cultuur-natuur en micro-macro zijn namelijk ongeschikt om het hybride karakter van veel hedendaagse criminologische problemen goed te kunnen begrijpen. Om hier het hoofd aan te bieden verwijst Marc Schuilenburg (2012) in zijn boek Orde in veiligheid naar het concept 'assemblage' van de Franse filosoof Gilles Deleuze en de daarvan afgeleide Actor-NetwerkTheorie (ANT) van de socioloog Bruno Latour, waarin de relaties en de interacties worden onderzocht tussen mensen, objecten en leefomgevingen.

In haar bijdrage aan dit themanummer past Wytske van der Wagen de 'lens' van Latours Actor-Netwerk-Theorie toe op de zogenoemde 'cyborg-criminaliteit', waarin zij computernetwerken als mede-actor beschouwt. Omdat mens en tech- 
niek in toenemende mate met elkaar verweven raken, dienen we als criminologen de mens namelijk niet langer het alleenrecht op actorschap toe te kennen. Van der Wagen baseert zich hierbij op haar promotieonderzoek naar verschillende vormen van technische en virtuele vormen van cybercrime, waaronder het geautomatiseerde karakter van 'botnets', de motieven en werkwijzen van hackers en de gevolgen van ransomware.

Ook Daan van Uhm kritiseert het antropocentrische karakter van de criminologie. Vertrekkend vanuit de theorie van het antropoceen, de periode waarin de aarde en de atmosfeer grote negatieve gevolgen ondervinden van menselijke activiteiten, ontwikkelt hij een groen-criminologisch perspectief waarin dieren en ecosystemen niet langer als object worden beschouwd, maar als subject; waarin de ecologische implicaties van het antropoceen in acht worden genomen en waarin de scheve machtsverhoudingen tussen 'the global North' en 'the global South' ter discussie worden gesteld. 'Ecocide' kan volgens Van Uhm worden beschouwd als een nieuw internationaal misdrijf tegen de menselijkheid - en tegen niet-menselijke dieren en ecosystemen.

Ook Bas van Stokkom benadrukt de maatschappijkritische kant van de culturele criminologie, door witteboordencriminaliteit te beschouwen als een 'normaal' uitvloeisel van het 'normale' kapitalistische proces, waarin (vaak onverantwoord hoge) risico's nemen (met andermans geld) en het 'willen winnen' zowel tot machtsillusies als tot een laatmoderne anomie binnen de zakenwereld hebben geleid.

Het mondialiseringsproces, en meer specifiek de betrokkenheid van multinationale ondernemingen bij mensenrechtenschendingen, staat centraal in de bijdrage van Annika van Baar. De spanning die kan ontstaan tussen mondiaal zakendoen en claims van eveneens mondiaal opererende mensenrechtenbewegingen, noodzaakt criminologen een scherp oog te ontwikkelen voor de (machts)verhoudingen tussen burgers, overheden en multinationale ondernemingen. In theoretische zin stelt Van Baar zich vooral de vraag of het concept 'state-corporate crime' ook toepasbaar is op en verklaringskracht heeft in samenwerkingsverbanden tussen bedrijven en niet-democratische overheden.

In haar bijdrage gaat Maartje Weerdesteijn in op een ander element van de toegenomen aandacht voor mensenrechtenschendingen als (mogelijke vorm van) 'state crime'. Zij wijst erop dat criminologen daarvoor meer kennis van internationale betrekkingen en internationaal strafrecht zullen moeten opdoen. Met name in het incorporeren van recente literatuur over 'global governance' ziet zij een belangrijke, noodzakelijke vernieuwing van de criminologie.

De Uruguayaanse criminoloog Nicolás Trajtenberg biedt een epistemologische bijdrage aan de ontwikkeling van de criminologie, waarin hij ingaat op een belangrijke vernieuwingsimpuls van de culturele criminologie, namelijk het inzicht dat het plegen van criminaliteit meestal weinig met instrumentele overwegingen van doen heeft, maar veel vaker 'gewoon' leuk en spannend is om te doen. Hij kent aan het benadrukken van deze emotionele drive een belangrijke vernieuwende rol toe, maar cultureel criminologen moeten volgens hem nog wel een stap verder gaan in hun verklaringen en niet alleen wijzen op de emotionele en aantrekkelijke kant van criminaliteit, maar er tevens een alternatief analysekader voor ontwik- 
kelen. Iets soortgelijks geldt volgens hem voor de relatie tussen beschrijven, begrijpen en verklaren, die in de culturele criminologie weliswaar anders lijkt te liggen, maar die epistemologisch nog nauwelijks is uitgewerkt.

De rubriek Doka ten slotte is geïnspireerd door het werk van de vorig jaar overleden Britse cultuurcriticus Mark Fisher - beter bekend als 'k-punk'.

Met deze artikelen hopen wij met dit themanummer niet alleen een bijdrage te hebben geleverd aan de verdere ontwikkeling van de culturele criminologie, maar zeker ook aan de theoretische vernieuwing van het vakgebied als zodanig.

\section{Literatuur}

Becker, H.S. (1963), Outsiders. Studies in the Sociology of Deviance. New York: Free Press. Becker, H.S. (1967), Whose side are we on?. Social Problems, (14), 239-247.

Beirne, P. \& C. Sumner (1997), Editorial statement. Theoretical Criminology, 1(1), 5-11.

Blokland, A.A.J., K. Thienpont \& A.G. Donker (2005), Biosociale perspectieven in de criminologie. Tijdschrift voor Criminologie, 47(2), 103-116.

Bouabid, A. (2018), De Marokkanenpaniek (diss. Rotterdam), 335 p.

Boutellier, H. (1993), Solidariteit en slachtofferschap. De morele betekenis van criminaliteit in een postmoderne cultuur. Nijmegen: Socialistiese Uitgeverij.

Boutellier, H. (2002), De veiligheidsutopie. Hedendaags onbehagen en verlangen rond misdaad en straf. Den Haag: Boom Juridische uitgevers.

Bunt, H. van de \& R. van Swaaningen (2003), Een nieuwe opleiding criminologie in Nederland. Panopticon, 24(1), 79-89.

Cohen, S. (1972), Folk Devils and Moral Panics; The Creation of Mods and Rockers. London: MacGibbon \& Kee.

Cullen, F.T. \& S.F. Messner (2007), The making of criminology revisited: An oral history of Merton's anomie paradigm, Theoretical Criminology, 11(1), 5-37.

Engbersen, G. (2008), Criminologie in meervoud: Over theoretische vernieuwing in de Nederlandse criminologie. Tijdschrift voor Criminologie, 50(3), 264-272.

Ferrell, J. (1998), Against the law: Anarchist criminology. Social Anarchism, 25, 5-23.

Fijnaut, C. (2014), Criminologie en strafrechtsbedeling: Een historische en transatlantische inleiding. Antwerpen: Intersentia / Den Haag: Boom.

Fiselier, J., E. Lissenberg, P. Moedikdo e.a. (red.) (1977), Tegen de regels; een inleiding in de criminologie. Nijmegen: Ars Aequi Libri.

Foucault, M. (1966 [2006]), De woorden en de dingen. Een archeologie van de menswetenschappen. Amsterdam: Boom.

Foucault, M. (1976), De orde van het vertoog. Meppel: Boom.

Garland, D. (2002), Of crimes and criminals: the development of criminology in Britain. In: M. Maguire, R. Morgan \& R. Reiner (red.), The Oxford Handbook of Criminology. Oxford: Oxford University Press, 7-50.

Giddens, A. (1984), The Constitution of Society: Outline of the Theory of Structuration. Berkeley: University of California Press.

Gouldner, A. (1968), The sociologist as partisan: Sociology and the welfare state. American Sociologist, 3, 103-116.

Haan, W.J.M. de (red.) (1998), Theoretische integratie, themanummer Tijdschrift voor Criminologie, 40(2).

Hirschi, T. (1969), Causes of Delinquency. Berkeley: University of California Press.

Kempe, G.Th. (1967), Inleiding tot de criminologie. Haarlem: Bohn. 
Kleemans, E., F. Weerman \& E. Enhus (2007), Theoretische vernieuwing in de criminologie. Tijdschrift voor Criminologie 49(3), 239-251.

Kleemans, E.R., D.J. Korf \& R. Staring (2008), Mensen van vlees en bloed. Kwalitatief onderzoek in de criminologie. Tijdschrift voor Criminologie, 50(4), 323-336.

Kuhn, Th.S. (1972), De structuur van wetenschappelijke revoluties. Meppel: Boom.

Kuhn, Th.S. (1979), De noodzakelijke spanning. Traditie en vernieuwing in de wetenschap. Meppel: Boom.

Merton, R.K. (1938), Social structure and anomie. American Sociological Review, 3, 672-682.

Merton, R.K. (1942 [1973]), The Normative Structure of Science, in: R.K. Merton, The Sociology of Science: Theoretical and Empirical Investigations. Chicago: University of Chicago Press.

Popper, K.R. (1935 [1959]), The Logic of Scientific Discovery. New York: Basic Books.

Putnam, R. (2000), Bowling Alone. The Collapse and Revival of American Community. New York: Simon \& Schuster.

Sampson, R.J. (2012), Great American City: Chicago and the Enduring Neighbourhood Effect. Chicago: University of Chicago Press.

Schuilenburg, M. (2012), Orde in veiligheid. Een dynamisch perspectief. Den Haag: Boom Lemma.

Schuilenburg, M., D. Siegel, R. Staring \& R. van Swaaningen (2011), Over cultuur en criminaliteit, Tijdschrift over Cultuur \& Criminaliteit, 0(1), 3-17.

Schuilenburg, M., R. Staring \& R. van Swaaningen (2017), Cultural criminology going Dutch: On culture, methodology and research agendas. In: K. Hayward (red.), Cultural Criminology: Critical Concepts in Criminology, chapter 53, Volume 3. Abingdon: Routledge, 252-272.

Schuilenburg, M. \& R. van Steden (2014), Positive security. A theoretical framework. In: M. Schuilenburg et al. (red.), Positive Criminology. Reflections on Care, Belonging and Security. Den Haag: Eleven International Publishing, 19-32.

Schuilenburg, M. \& R. van Swaaningen (2014), Criminologie en strafrechtsbedeling: een boekbespreking. Tijdschrift voor Criminologie, 56(4), 157-163.

Smart, C. (1976), Women, Crime and Criminology. A Feminist Critique. London: Routledge \& Kegan Paul.

Staring, R. \& R. van Swaaningen (2016), Kwalitatief onderzoek en criminologische theorie: Over de relatie tussen theorie, onderzoeksvragen en methode. In: T. Decorte \& D. Zaitch (red.), Kwalitatieve methoden en technieken in de criminologie (derde editie). Leuven: Acco, 33-80.

Sutherland, E.H. (1940), White-collar crime. American Sociological Review, 5(1), 1-12.

Swaaningen, R. van (1997), Critical Criminology - Visions from Europe. London: Sage.

Swaaningen, R. van (2007), Naar een kosmopolitische criminologie. In: H. van de Bunt, P. Spierenburg \& R. van Swaaningen, Drie perspectieven op sociale controle. Den Haag: Boom Juridische uitgevers, 17-65.

Swaaningen, R. van (2014), De Nederlandse Vereniging voor Criminologie en de ontwikkeling van het vakgebied tussen 1974 en 2014. Tijdschrift voor Criminologie, 56(3), 84-99.

Young, J. (1971), The Drugtakers. The Social Meaning of Drug Use. London: Paladin. 